\title{
Sustainable Financing for Biogas Fuel from Palm Oil Industry Waste
}

\author{
Sukirman YA ${ }^{1 *}$, Fachrurrozie Sjarkowi ${ }^{2}$, Joni Emirzon ${ }^{3}$ and Inten Meutia ${ }^{4}$ \\ ${ }^{1}$ Department of Environmental Science, Sriwijaya University, Indonesia \\ ${ }^{2}$ Faculty of Agriculture, Sriwijaya University, Indonesia \\ ${ }^{3}$ Faculty of Law Science, Sriwijaya University, Indonesia \\ ${ }^{4}$ Faculty of Economics, Sriwijaya University, Indonesia
}

Submission: April 06, 2018; Published: April 12, 2018

*Corresponding author: Sukirman YA, Department of Environmental Science, Graduate School, Sriwijaya University, Palembang, Indonesia, Email: yudhiapriyadi86@gmail.com

\begin{abstract}
Sustainable development as a new paradigm in generating economic growth has gained the attention and commitent of many institutions and countries. This issue is so important, that the United Nations in cooperation with various governments, civil society and other economic players have developed a sustainable development framework that is expected to bring economic and environmental sustainability interests together, provide economic transformation process, and expand access for the poor to get out of poverty, and enforce justice. This also takes into account that the social and environmental issues which have not been included in the economic calculations have become important elements that need to be considered. In particular, environmental sustainability is examined to better understand its impact on consumers and firm performance. We introduced Sustainable Financing, which is used as variable to implementing financial institutions' lending policies. Sustainable finance supporting the principles of sustainable development namely the 4P (pro-growth, pro-jobs, pro-poor, and pro-environment). Due to the high energy requirements to support development, sustainable finance activities will give priority to the development of new renewable energy and energy conservation from Biogas Fuel escpecially based on Palm Oil Industry waste. In the long term, the distribution of sustainable financing to strategic sector industries is expected to encourage sustainable economic growth, which in turn will provide a larger market for financial services institutions.
\end{abstract}

Keyword: Sustainability; Risk management; Lending policies; Equator principles; Banking industry; Renewable energy practices

Abbreviations: GHG: Green House Gas Emission; GRI: Global Reporting Index; EP: Equator Principles; GRI: Global Reporting Initiative; UNEPFI: United Nations Environment Programme-Finance Initiative; SMI: Sarana Multi Infrastruktur; ESI: Energy Saving Insurance; PAEP: Pollution Abatement Equipment program

\section{Introduction}

A number of global initiatives from several financial institutions worlwide were established to support sustainable development, such as the RIO+ Agreement which includes the commitment of developed countries to reduce greenhouse gas emissions globally and to help developing countries to also undertake economic development programs that are environmentally friendly. According to Ngwakwe [1] argues that there is 3 Indicators of sustainability: employee health and safety, waste management, and community development. Ameer \& Othman [2] realizing the importance of sustainable development in Scores on 4 Sustainability Indices including items for environment, diversity, community and ethical standards. Sustainable finance is defined as comprehensive support from the financial service industry to achieve sustainable development resulted from a harmonious relationship between economic, social and environmental interests. Brunhubber S [3] argue that Sustainable finance achieve industry, social and economic superiority in order to address the threats of global warming and mitigate other environmental and social issues.

Indonesia as one of the G20 countries, has also demonstrated its commitment to reduce greenhouse gas emissions by 2020 at the Pittsburgh Summit in 2009. Indonesia's commitment to reduce GreenHouse Gas emission (GHG) by $26 \%$ at its own expense or up to a $41 \%$ reduction with international support has been translated into a National Action Plan for the Reduction of Greenhouse Gas Emission. The plan states that the 26\% reduction of greenhouse gas emissions will come from forestry and peatland 50\%, energy and transportation 3,8\%, agriculture $18 \%$, industry $1,8 \%$ and waste $5,9 \%$. Furthermore, the government has also incorporated the sustainable development 
framework in the Medium and Long Term Development Plan that comprises four aspects of sustainable development, namely the social, economic, environmental and institutional aspects.

Sustainable finance aims to encourage the shifting of the target towards a competitive low carbon economy and supporting the principles of development namely the 4P (pro-growth, projobs, pro-poor, and pro-environment) [4]. Sustainable finance based on Risk Management Principle which integrates aspects of environmental and social protection in Financial Services Institution's risk management to avoid, mitigate and minimize the negative impacts that may arise and promote increased value in the Financial Services Institution's financing and operational activities. Costa Infante et al. [5] use sustainable financing based on Sustainable Priority Economic Sector Development Principle that is inclusive by increasing financing activities primarily in the industry, energy, agriculture (in the broadest sense), infrastructure and MSME sectors and at the same time striking a balance between the economic, environmental and social aspects; and provides financial services to the community who has limited or no access to financial services in the formal sectors. Another example is Qin Y et al. [6], who based on sustainable financing from Environmental and Social Governance and Reporting Principle by implementing robust and transparent environmental and social governance practices in the Financial Services Institution's operational activities as well as ensuring that the same environmental and social governance practices are implemented by the Financial Services Institution's clients; and periodically reports the progress of Financial Services Institution's in implementing the principles of sustainable finance to public.
We focus, on the sustainable financing as a decision tool for financial institution'sbased on operational activities implementing robust and transparent environmental and social practices that applies in crude palm oil waste which produces biogas industry in South Sumatera. The main goal of this paper is to present a new way to Financial Services Institution's provide financing resources required by the public by using the pro-growth, pro-job, pro-poor and pro-environment as points of reference and Improve the Financial Services Institution's resilence and competitiveness to enable them to grow and develop in as sustainable manner. Resilience is associated with improved Financial Services Institution's ability to innovate and produce environmentally friendly products or services [7].

\section{Methodolgy}

Measurable of Sustainability financing used Sustainability Report Qualtiy Content Aanalysis Score based on 18 sustainability performance indicators as per Global reporting Index (GRI) and score on likert scale. In the present case, the Sustanable Financing for Renewable Energy would complement regular credit rating models by yielding qualitative and quantitative information that would lead to improved decision-making. For example, let's assume that companies would be rated in the same way as in regular credit models, with sustainability worthiness ranging from triple $\mathrm{S}$ (prime borrowers) to D (default). Research assumes a company with a low sustainability rating, below investment grade (in the BB range or lower). This could mean increased interest rates which given or denial of credit by the, even if the company is otherwise creditworthy. Conversely, companies with high sustainability ratings could get preferred treatment, either in terms of costs or access to capital.

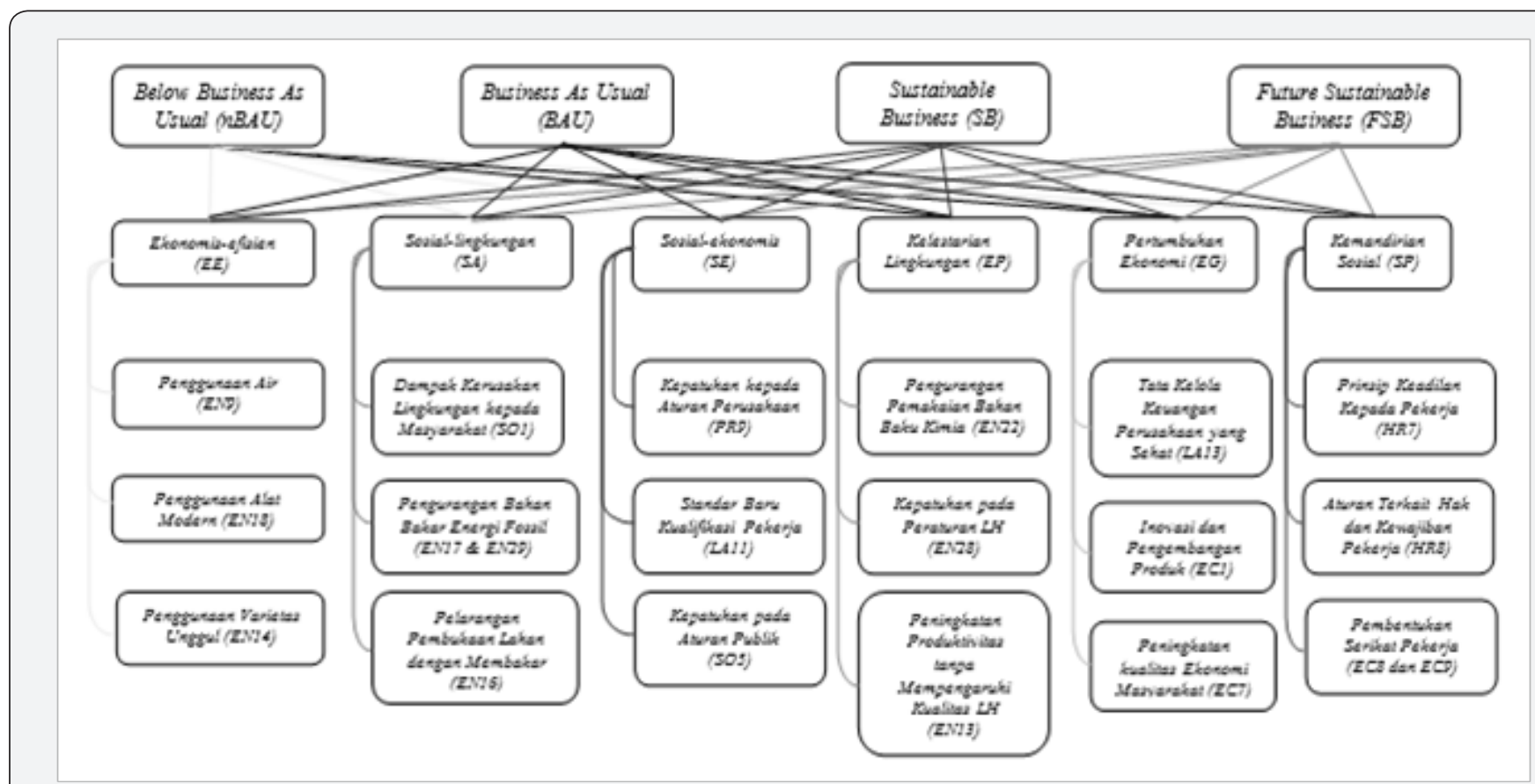

Figure 1: AnalyticalHierarrcyProcessatcrude palm oil industry practices with an analysis of the Global Reportinglndeks. 
The Indonesian Banking industry uses the same criteria as in most countries, based on Basel standards. In the present case, Indonesia Bank is chosen, which are observed by 70 financial institutions committed to not provide loans to projects worth USD 10 million or more if the prospective debtor does not comply with the prevalling social and environmental regulations and follow procedures established by the Equator Principles (EP). The United Nations Environment Programme-Finance Initiative (UNEP-FI) which established since 1972 to 2016 has member more than 200 financial institutions. The Global Reporting Initiative (GRI) Is another internatioanl Initiative. The GRI guidelines were adopted from the UN Environment Programme (funded by the UN Development Fund), and serves as one of the guidelines in developing sustainability reports. A Sustainability report is a report made by a company in order to disclose or communicate to all stakeholders on its economic, environmental and social performances accountably.

The Sustainable Financing analysis methodology combines an examination of the crude palm oil industry practices with an analysis of the Global Reporting Index Sustainable Classification.
It forms the basis for all the subsequent analyses [8]. Relating it to GRI allows us to decide on the major issues that crude palm oil companies and consequently the crude palm oil industry have to address in the coming decades Figure 1.

\section{Results and Discussion}

Strategic activities to implement sustainable finance comprise of 3 (three) focus area as follows:

a. Increase supply of environmentally friendly financing,

b. Increase demand of environmentally friendly financing products, and

c. Increase oversight and coordination of sustainable finance implementation.

The result from the GRI G4 analyses indicate 70 issues relevant to the sustainability of the Crude Palm Oil Industry. On this set of issues, further analysis is carried out, and researcher select 34 critical issues. Those issues are developed in eight categories.

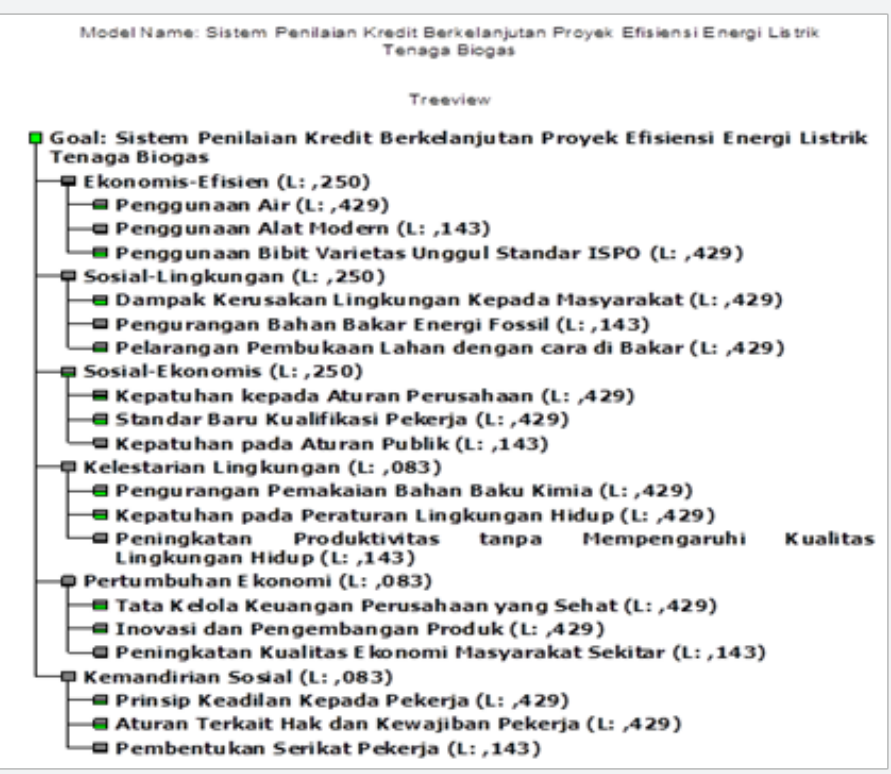

Figure 2: Analyzed Sustainability Dimensions with Expert Choice 11 Program.

For the measurements we used SCSS and analyzed with Expert Choice 11 program, we need to assign weights to the different development paths and the different sustainability dimensions. We use subjective criteria. The subjective criteria are going to be validated through the testing of the questionnaire in the field through successive iterations of the process. After testing it with some companies, the last measurements should be evaluated and then the criteria can be refined. There is no inherent problem with qualitative and subjective criteria in credit risk modeling in general, which has a long tradition. Financial Services Authority today is calling for more subjectivity in their credit risk models, a point that is contentious in the financial literature Figure 2.
Renewable energy project sustainable financing generally comes from banking institutions and non-banking institutions such as multilateral institutions or financial institutions which established by the government. Some government and banking financing schemes such as:
a. Revolving Fund;
b. Investment Credit Scheme;
c. "Murabahah" Sharia Financing Scheme;
d. "Musyarakah" Sharia Financing Scheme;
e. "Mudharabah" Sharia Financing Scheme. 
In order to accelerate the development of national infrastructure, Government attracting private funds both from local or international investor and established PT. Sarana Multi Infrastruktur (SMI). PT SMI developing various project financing at the renewable energy such as:

a. Subordinated Loan Facility Scheme

b. Equity Investment Scheme.

Another alternative financing scheme for renewable energy project such as:

a. Pooled Bond Financing; b. Utility On-Bill Financing;

c. On-Bill Repayment;

d. Loan Purchase Program;

e. $\quad$ Energy Saving Insurance (ESI);

f. Linked Deposit program.

In this research, we only explain bankgreen lending modeltogether with insurance. Figure 3 below summarizes the whole process in the banking green lending model together with insurance.

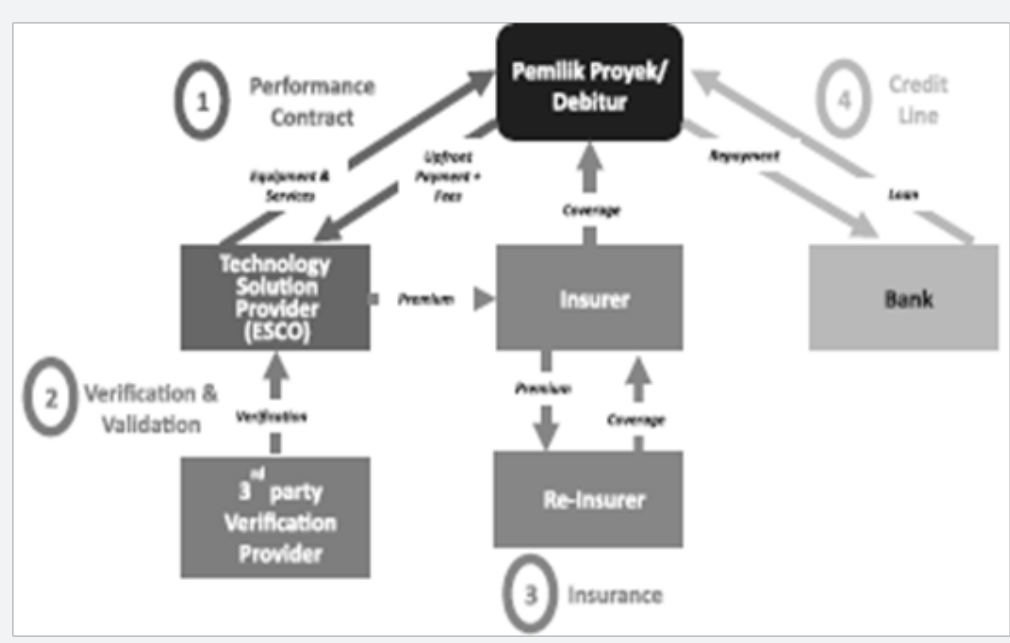

Figure 3: The whole process in the bankgreen lending model together with insurance.

\section{Conclusion}

One of the obstacles in increasing environmentally friendly financing in priority economic sectors is the lack of understanding of the market or business on the financing potential of environmentally friendly projects as well as risk assessment and mitigation of renewable energy projects. The lack of understanding of risk management and mitigation that can be done make business less enthusiastic in becoming first movers of environmentally friendly projects; in addition there is also a lack of dissemination of information and lessons learned on the implementation of environmentally friendly projects in other countries.

The sustainable finance program not only seeks to increase financing but also to increase durability and competitiveness of financial services institutions. The development orientation to increase durability and competitveness is based on the premise that sustainable finance is a challenge and a new opprtunity that FSI can benefit from to grow and develope more stably. Sustainability will be a deciding factor in risk models by commercial banks. We argue that developing SCSS and Green Lending Model for Renewable Energy Project can provide value creation for a bank and positive externalities to society.
Financing increase in the banking industry is done by means of requiring a specific percentage of the total financing portfolio of each bank to be allocated to support the priority sectors and assigning certain banks who are deemed equipped with capabilities in specific areas such as financing increase programs in Pollution Abatement Equipment program (PAE Program) which provided financial assistance to support simple and affordable environmental financing.

The oversight of the sustainable finance program implementation will be done through the strengthening of risk management, corporate governance in environmental and social aspects, as well as the acceleration of the implementation of the Environmental Law. The policy/regulation umbrella to support the implementation of sustainable finance shall comprise of General policies on Sustainable finance Principles that governs the Financial Services Institution's obligations to observe the balance of the $4 \mathrm{P}$ (pro-growth, pro-jobs, pro-poor, and proenvironment), protection and management of natural resources, as well as all parties participation in every financing activities in Indonesia.

\section{References}

1. Ngwakwe (2009) Identification Indicators of sustainability, employee health and safety, waste management and community development at 


\section{Recent Advances in Petrochemical Science}

manufacturing companies in Nigeria. Business Ethics Journal 89: 833849.

2. Ameer, Othman (2012) Scores on Sustainability Indicates for environment, diversity, community and ethical standards on top 1 oo global sustainable companies. Low Carbon Economy Journals : Comprehensive Works 2(5): 112-118.

3. Brunhubber S (2015) How to Finance our Sustainable Development Goals (SDGs): Socio ecological Quantitative Easing (QE) as a Parallel Currency to Make the World a Better Place. Social Science Journals: Comprehensive Works 2(5): 112-118.

4. Cordeiro, James J, danTewari, Manish (2015) Company Characteristics, Industry Context, and Investor Reactions to Environmental CSR: A Stakeholder Theory Approach. Business Ethics Journal 130: 833-849.
5. Infante CEDC, Costa L, Moura E, Valle DR (2016) Multi-criteria Comparison of Sustainability in Brazilian, American and European Banks. British Journal of Applied Science \& Technology 13(6): 1-13.

6. Qin Y, Wang H, Wang K, dan Li Z (2014) Discussion on the Integrated Financing Model of EMC and Carbon Trading. Low Carbon Economy Journal 5(3): 126-131.

7. Casado AJ danSteurer R (2014) Integrated strategies on sustainable development, climate change mitigation and adaptation in Western Europe: communication rather than coordination. Journal of Public Policy 34(3): 437-473.

8. Mokhtar S, dan Deng YS (2015) Identification of Key Forces Influencing Sustainable Development in Taiwan. Journal of Sustainable Developmen 8(2): 174-186.

\section{Your next submission with Juniper Publishers will reach you the below assets}

- Quality Editorial service

- Swift Peer Review

- Reprints availability

- E-prints Service

- Manuscript Podcast for convenient understanding

- Global attainment for your research

- Manuscript accessibility in different formats ( Pdf, E-pub, Full Text, Audio)

- Unceasing customer service

Track the below URL for one-step submission https://juniperpublishers.com/online-submission.php 